DOI: 10.19195/0137-1150.163.35

\author{
ANNA URSULENKO \\ Uniwersytet Wrocławski, Polska \\ annie.ursulenko@gmail.com
}

\title{
Czy naród jest jak wino - im starszy tym lepszy? (Od)tworzenie genealogii narodu a strategie narodotwórcze
}

Symbolika starości jest ambiwalentna, może bowiem przekazywać przeciwstawne idee i ewokować rozbieżne interpretacje. Określenia „starość”, „stary” również w przeniesieniu na kulturoznawczy grunt rozważań nad wspólnotami narodowymi czy politycznymi mogą być traktowane dwojako. Nadanie w wypowiedzi jakiemuś zjawisku przymiotów zaawansowanego wieku może być użyte dla zaznaczenia wartościującego, negatywnego stosunku do omawianej kwestii. Na przykład schyłkowy okres Związku Radzieckiego jest często określany jako okres gerontokracji lub rządów kremlowskich starców. To nie tylko odwołanie się do greckiego określenia ustroju państwowego opartego na rządach ludzi w podeszłym wieku, lecz także wartościująca charakterystyka atmosfery tamtych lat: marazmu, beznadziei, niezdolności do podejmowania konstruktywnych decyzji, indolencji i uwstecznienia. Zapewne podobne intencje przyświecały również Zbigniewowi Brzezińskiemu, który krytykując niedawno politykę międzynarodową Unii Europejskiej, stwierdził, że Unia zamienia się w „,komfortowy dom starców”. Polityk kontynuuje w ten sposób zwyczaj krytykowania „staruszki Europy” jako podmiotu biernego, niegotowego do podjęcia różnego typu wyzwań, gracza politycznego, który już wyczerpał swoje siły witalne. W takim ujęciu kompleks tego, co określa się jako „stare”, jest traktowany jako antonim nowych pomysłów, innowacyjnych rozwiązań, dynamicznego rozwoju. Również ruchy rewolucyjne bardzo często odwołują się do opozycji stary-nowy, przeciwstawiając anachroniczny, niesprawiedliwy i opresyjny w swej skostniałości porządek, który należy zburzyć, oraz świat przyszłości, który ma być zbudowany na kompletnie nowych zasadach. 
Jednocześnie użycie metafory starości w odniesieniu do tematyki narodowej bardzo często ma za zadanie wywołać zgoła inne konotacje. Epitet „stary” oznacza wtedy dawny rodowód, szlachetność pochodzenia, wielowiekowe doświadczenie, autorytet oparty na długiej tradycji. Podążanie takim tokiem rozumowania nieuchronnie stawia $\mathrm{w}$ centrum uwagi zagadnienia historii i pamięci historycznej. Niemniej jednak pełne zrozumienie wizji historii powstających w danym kraju nie jest możliwe bez wiedzy o okolicznościach, w których rodzą się rozpatrywane koncepcje. Jak twierdzi bowiem Enzo Travesto: „Historia wpisuje się zawsze w teraźniejszość. Liczne dzieła historyczne mówią nam więcej o swojej epoce, wyjaśniając jej świat wyobrażeń i jej idee, niż o przeszłości, której tajemnice chciałyby przeniknąć"1.

$\mathrm{Z}$ wielu powodów pamięć historyczna na Ukrainie znajduje się w centrum uwagi debaty społecznej od chwili uzyskania przez ten kraj niepodległości. W dyskusji panelowej poświęconej polityce historycznej na Ukrainie polski polityk Adam Rotfeld zauważa, że „wynika to przede wszystkim z konieczności budowania nowej tożsamości. Kraj, który odzyskał suwerenność, musi na nowo kształtować swoją tożsamość"2. Zatem doniosłość dociekań historycznych dodatkowo jest potęgowana przez tezę o nierozłącznej relacji pamięci i tożsamości narodowej. Jest to przeświadczenie zgodne z ustaleniami współczesnych teorii pamięci zbiorowej, które pomimo zróżnicowania, jak stwierdza Magdalena Saryusz-Wolska, łączy wspólne przekonanie o tym, że „,zbiorowe pamiętanie krystalizuje zbiorową tożsamość" ${ }^{3}$. Współczesne autorytety z zakresu tej dyscypliny na licznych przykładach ilustrują, w jaki sposób tożsamość grupy społecznej i jej pamięć ,warunkują się wzajemnie i niezbywalnie”4. Innymi słowy, to, „kim jesteśmy”, w znaczącej mierze zależy od tego „skąd pochodzimy”, a dokładniej od tego, jakie wyobrażenia o swoim pochodzeniu pielęgnujemy i pragniemy przekazać następnym pokoleniom. Jak pisze Jerzy Wyrozumski:

świadomość własnej przeszłości jest elementarną potrzebą jednostki ludzkiej, grupy etnicznej, narodu. Rodzi się wraz z poznawaniem otoczenia, świata i staje się bardzo ważnym składnikiem kultury, jej siłą sprawczą i zarazem tworzywem ${ }^{5}$.

Podobnego zdania jest również Stefan Kozak, który stwierdza, że naród przekonany o swoim mocnym osadzeniu w historii czuje się bezpieczny ${ }^{6}$. Zwrot-

${ }^{1}$ E. Traverso, Historia jako pole bitwy. Interpretacja przemocy w XX wieku, tłum. Ś.F. Nowicki, Warszawa 2014, s. 12-13.

2 A.D. Rotfeld, Dyskusja: Polityka tożsamości i pamięci na Ukrainie, [w:] Pamięć i pytania o tożsamość. Polska. Ukraina, red. T. Horbowski, P. Kosiewski, Warszawa 2013, s. 27.

${ }^{3}$ M. Saryusz-Wolska, Wprowadzenie, [w:] Pamięć zbiorowa i kulturowa. Wspótczesna perspektywa niemiecka, red. M. Saryusz-Wolska, Kraków 2009, s. 20.

4 J. Assman, Kultura pamięci, [w:] Pamięć zbiorowa i kulturowa..., s. 78.

5 J. Wyrozumski, Mity o pochodzeniu, [w:] Współcześni Stowianie wobec własnych tradycji i mitów, red. M. Bobrownicka, L. Suchanek, F. Ziejka, Kraków 1997, s. 15.

${ }^{6}$ S. Kozak, Ukraiński dialog z tradycją kultury narodowej, [w:] Współcześni Stowianie..., s. $159-160$. 
ne momenty dziejowe dodatkowo intensyfikują eksplorację materiału historycznego. W przełomowych momentach ludzie są skłonni odrzucać przestarzałe ideologiczne koncepcje na rzecz nowych, które bardziej odpowiadają duchowi czasu i zaistniałym realiom społeczno-politycznym. Jednak pojawieniu się nowych koncepcji z reguły towarzyszy znaczna ilość „intelektualnych plew”: religijnych herezji, quasi-ideologii, pseudonaukowych koncepcji. Dochodzi do tego między innymi wtedy, gdy w dyskursie narodowym zaczyna dominować imperatyw odbudowania pamięci genealogicznej i zwycięża potrzeba sięgania jak najdalej wstecz do „początków”, do „pochodzenia”. Poszukiwanie mitu początku przyczynia się do naiwnej chęci upatrywania początków własnego narodu $\mathrm{w}$ najbardziej zamierzchłych czasach oraz prowokuje sięganie w trakcie konstruowania szlachetnej narodowej genealogii do najdalszej przeszłości. Ponadto narodocentryczna optyka sprawia, że to rozmiłowanie w odległej genealogii nierzadko bywa także obarczone megalomanią i ksenofobią. I właśnie temu ogniwu ukraińskich strategii z zakresu nation building będzie poświęcony niniejszy artykuł, niepretendujący na wyczerpujące przedstawienie wszystkich koncepcji etnogenezy funkcjonujących na Ukrainie po 1991 roku.

W opublikowanej w 2000 roku monografii pt. The Ukrainians: Unexpected Nation Andrew Wilson pisał: „Obecnie nawet badacze należący do głównego nurtu historiografii ukraińskiej skłonni są raczej dowodzić, że Ukraińcy i ich przodkowie od tysięcy lat zamieszkiwali te same ziemie, co obecnie"8. W takim ujęciu wspólnota etniczna jest traktowana jako odwieczny, wręcz pozahistoryczny twór, zalążek przyszłego narodu rozumianego (czy też wyobrażonego, według B. Andersona) jako wspólnota krwi i terytorium. Cechy dystynktywne wspólnoty etnicznej zgodnie z takim podejściem służą jako niezmienna baza cywilizacyjnych wzorów i kulturowych imponderabiliów dla narodu, który z niej „wyrasta” niejako w linii prostej ${ }^{9}$. Jednak na kanwie tak konstruowanej teorii etnogenezy, możliwej do zaakceptowania przez świat akademicki w ramach prymordialistycznego podejścia, wyrósł cały szereg alternatywnych wersji dziejowych, w których, jak zaznacza Wilson, ,rzetelna prawda historyczna przeplata się z najdziwaczniejszymi płodami wybujałej imaginacji, a im dalej sięgają one

${ }^{7}$ Відкритийлист редколегї̈журналу „Археологія” до мас-медіа України, „Археологія” 2012, nr 3, s. 144.

${ }^{8}$ A. Wilson, The Ukrainians: Unexpected Nation, Yale University Press, 2000. Tu i dalej cytuję za polskim wydaniem: A. Wilson, Ukraińcy, tłum. M. Urbański, Warszawa 2004, s. 22.

${ }^{9}$ W 2015 roku na Ukrainie ukazały się dwie prace autorstwa uznanych autorytetów w dziedzinie ukraińskiej historiografii zajmujące się okresem początkowych dziejów Rusi Kijowskiej i reprezentujące odmienne, modernistyczne podejście do pojęć narodu i tożsamości narodowej. Monografie proponują więc rewizjonistyczny stosunek do ustalonych prymordialistycznych schematów opisujących epokę średniowiecza w kategoriach (takich jak naród czy państwo narodowe) wykształconych dopiero w nowożytności. С. Плохій, Походження слов'янських начій. Домодерні ідентичності в Украӥні, Росії та Білорусі, Київ 2015; А. Толочко, Очерки начальной Руси, Киев 2015. 
w przeszłość, tym bardziej bywają niecodzienne"10. Warunki sprzyjające powszechnej popularyzacji egzotycznych teorii autorstwa Jurija Kanyhina, Jurija Szyłowa, Ołesia Berdnyka czy Lwa Syłenki zaistniały na Ukrainie po odzyskaniu przez ten kraj niepodległości. Idee te zyskały posłuch u niemałej części społeczeństwa ukraińskiego, zwłaszcza, jak zauważa Ihor Bohdanowski, w tych kręgach inteligencji, które były żywo zainteresowane kwestiami odrodzenia narodowego ${ }^{11}$. Ponadto różnorodne fantazje na temat dalekiej przeszłości Ukraińców zaczęły przepełniać radio, programy telewizyjne, prasę, internetowe portale, a także półki ukraińskich księgarń ${ }^{12}$. Zgodnie $\mathrm{z}$ takiego typu paranaukowymi ustaleniami Ukraińcy są jednym z najstarszych narodów, albowiem ich przodkowie Oriowie-Ariowie byli znani już w IX wieku przed naszą erą. Powołując się na dyskusyjne obliczenia i w oparciu o drewniane tabliczki Księgi Welesa, twierdzi się, iż to właśnie Oriowie-Ariowie utworzyli Scytię i Państwo Antów, przyczynili się do powstania sanskrytu i wywarli wpływ na rozwój innych starożytnych cywilizacji, między innymi perskiej, egipskiej czy greckiej ${ }^{13}$. Głoszenie podobnych poglądów wpisywało się w szerszy nurt kontynuowania romantycznej mitologii narodowej, ale w jej skrajnej, hipertroficznej postaci. Przykładem takich przedsięwzięć realizowanych na Ukrainie był na przykład neopogański „projekt etnograficzny” (wedle określenia O. Hnatiuk), który usiłował powiązać ideologię narodową z mitem narodowym wywodzącym się z ery przedchrześcijańskiej. W poszukiwaniach dowodów na starożytność narodu ukraińskiego takie dzieła, jak Księga Welesa (mistyfikacja literacka podawana jako „święta księga” Praukraińców) czy monografia Droga Ariów. Ukraina w duchowej historii ludzkości Jurija Kanyhina zyskiwały rangę wiarygodnego świadectwa i wykładni „antycznej” historii Ukrainy.

Jedną z głównych tez popularnych interpretacji Księgi Welesa, jak zaznacza ukraiński badacz Dmitrij Gorun, jest to, że każdy naród powinien mieć swoją odrębną wiarę, a chrześcijaństwo zniszczyło autentyczną wiarę narodu ukraińskiego. Konkluzja jest taka, że podstawowym zadaniem współczesnych jest odbudowanie genetycznej pamięci narodu ukraińskiego. Opracowuje się w tym celu nową pogańską kosmogonię - między innymi reaktywuje się panteon dawnych bóstw słowiańskich ze Swarogiem-stwórcą i Perunem-przywódcą na czele $^{14}$. W takim ujęciu mit „starożytności” Ukraińców oprócz zabarwienia etnocentrycznego pozyskuje również „aureolę” religijną. Pseudonaukowe historyczne koncepcje trudno niekiedy odróżnić od neopogańskich tekstów religijnych. Z jed-

${ }^{10}$ A. Wilson, op. cit., s. 22.

${ }^{11}$ І.В. Богдановський, Відновлення національно-духовних традицій в сучасному язичництві, „Вісник Київського національного університету імені Тараса Шевченка. Філософія. Політологія" 2012, z. 107, s. 10.

12 Відкритий лист редколегії журналу „Археологія”..., s. 143.

13 D. Gorun, Mity współczesnej Ukrainy: krótki przegląd, „Sprawy Narodowościowe” 2002, z. 21 , s. $184-185$.

14 Ibidem. 
nej strony zdarza się, że sami twórcy zabiegają o nadanie swoim teoriom wymiaru mistyczno-sakralnego. Tak Wołodymyr Szajan, z którego nazwiskiem są związane początki ukraińskiego neopogaństwa, poczynając od lat czterdziestych $\mathrm{XX}$ wieku najpierw we Lwowie, a potem na emigracji tworzył ideowe podwaliny i rozwijał organizacyjną strukturę nurtu religijnego, zwanego Ridna Wira. Z kolei adept tej doktryny, Lew Syłenko, który z czasem sam ogłosił się prorokiem i napisał nową ,świętą księgę” Ukraińców pt. Maza Bipa, stworzył w 1964 roku własną religię pod nazwą RUNWira (Ridna Ukrajinska Nacjonalna Wira) ${ }^{15}$.

Jej zasięg ograniczony był początkowo do kręgów emigracji ukraińskiej w Ameryce Północnej, po 1991 roku jednak RUNWira pojawiła się również na Ukrainie, gdzie do 1998 roku powstało 35 gmin jej wyznawców ${ }^{16}$.

Zgodnie z danymi zawartymi w corocznych raportach ukraińskiego Państwowego Departamentu ds. Narodowości i Religii na terenie Ukrainy w 1997 roku funkcjonowało 29 zarejestrowanych wspólnot religijnych o charakterze pogańskim, natomiast zgodnie ze stanem na 1 stycznia 2015 roku ta liczba ogółem wynosiła 132 (w tym 62 gminy RUNWiry) ${ }^{17}$.

$\mathrm{Z}$ drugiej strony można mówić o parareligijnym charakterze podobnych teorii, ponieważ przekonanie o ich wiarygodności opiera się nie na faktach czy regułach logiki, lecz na zasadach wiary, a ich zwolennicy tworzą swoiste sekty ${ }^{18}$. Obiektem wiary zaś stają się przekazy o przewadze pierwiastków irracjonalnych i zamknięte na próby obiektywnej weryfikacji naukowej. Tworzy się w ten sposób swego rodzaju świeckie dogmaty narodowe, które zyskują zwolenników również w środowisku ukraińskiego ruchu prawicowo-radykalnego (zwłaszcza wśród wyznawców etnicznego nacjonalizmu ${ }^{19}$. Tak dzieje się na przykład w przypad-

15 I. В. Богдановський, op. cit., s. 10.

16 A. Wilson, op. cit., s. 37.

17 Дані Державного департаменту у справах національностей та релігій, http://risu.org. ua/ua/index/resourses/statistics/ukr2015/60129/ [dostęp: 2.02.2016]. Jednak zdaniem Wołodymyra Rohatina, mówiąc o organizacyjnej strukturze ruchu neopogańskiego, należy wziąć pod uwagę, że neopoganie byli słabo zinstytucjonalizowani i praktycznie nie wkładali wysiłku w tworzenie swojej struktury z ośrodkami w różnych regionach. В.М. Рогатін, Модифікаиіï язичництвва в сучасному неоязичництві, „Історичний архів. Наукові студії: збірник наукових праць” 2012, z. 9, s. 171.

18 Л. Залізняк, Україногенез в тумані міфологї̈, http://nestor-ua.org/projects/etnogenez-ua5. html [dostęp: 2.02.2016].

19 Е. Андрющенко, Украӥнські праворадикальні організації у контексті суспільнополітичних процесів (кінець 1980-х-2015 pp.), http://shron.chtyvo.org.ua/Andriuschenko_Eduard/Ukrainski_pravoradykalni_orhanizatsii_u_konteksti_suspilno-politychnykh_protsesiv_kinets_1980-kh__20.pdf [dostęp: 2.02 .2016 ]. Jeżēi chodzi o akceptację całokształtu neopogańskich idei narodowo-religijnych w środowisku ukraińskich nacjonalistów, to według E. Andriuszczenki pozyskaniu sympatyków w tych kręgach sprzyjało między innymi przeciwstawianie przez neopogan „narodowego" charakteru ich religii „obcemu”, „kosmopolitycznemu” chrześcijaństwu. I chociaż na poziomie nacjonalistycznych organizacji wpływ neopogaństwa był nieznaczny, to większość aktywistów ukraińskiej radykalnej prawicy, jak stwierdza badacz, miała do neopogan stosunek neutralny lub przychylny. 
ku aryjskiego wątku różnorakich teorii o starożytnym pochodzeniu Ukraińców. Zgodnie z tymi wyobrażeniami Ukraińcy są bezpośrednimi i jedynymi właściwymi spadkobiercami legendarnych Ariów. Jak podaje Andrew Wilson:

Utrzymuje się, że pierwszą „właściwą” cywilizacją aryjską na Ukrainie była archeologiczna kultura trypilska (lub trypolska), nazwana tak od podkijowskiej wioski Trypile (Trypole) nad Dnieprem. [...] Zasięg kultury trypilskiej nie ograniczał się do ziem ukraińskich, mimo to niektórzy badacze ukraińscy [...] uważają, że dostarcza ona niepodważalnych dowodów istnienia cywilizacji „wczesnoukraińskiej”, a nawet państwa zwanego „Arratą”. [...] Arrata była, zdaniem Ukraińców, „,pierwszą po potopie cywilizacją na kuli ziemskiej”, która dała ludzkości „,nowoczesne” techniki uprawy roli na długo przedtem, „zanim powstały kultury Egiptu i Sumeru"20.

Należy zaznaczyć, że przekonanie o trypilskiej genezie narodu ukraińskiego wyszło daleko poza krąg wyznawców neopogańskich religii czy zwolenników nacjonalizmu ukraińskiego. Nierzadko z takiej wizji ukraińskiej Arkadii czerpali inspiracje dla siebie politycy, artyści czy przeciętni Ukraińcy ${ }^{21}$. Innymi słowy, mit ukraińskiego Trypilla stał się częścią historii popularnej, elementem masowej świadomości historycznej Ukraińców. Dlaczego tak się stało? Po pierwsze, mamy tu do czynienia z przykładem współzależności takich procesów, jak sięganie do przeszłości i kształtowanie pozytywnego autostereotypu narodowego. Stereotypu, który pełni ważne funkcje integracyjne i obronne oraz pozostaje w wyraźnym związku z procesem kształtowania tożsamości zbiorowej. Jednocześnie widoczny obecnie na Ukrainie wzrost zainteresowania epoką starożytną stanowi doskonały przykład działania mechanizmów psychospołecznych typowych dla społeczeństwa postkolonialnego. Znaczna bowiem część ukraińskich chimer historycznych to swoiste antidotum na kompleks „młodszego brata” w stosunku do Rosji, a także reakcja na permanentne - transmitowane z pozycji ideologii radzieckiej oraz imperialnorosyjskiej — odmawianie Ukraińcom prawa do posiadania własnej, odrębnej historii. Mit narodowoukraiński (wedle określenia Dmitrija Goruna) wyrasta zatem z potrzeby budowania bardzo korzystnego stereotypu narodu ukraińskiego. Jednak w modelu hipertroficznie pozytywnego autostereotypu ukraińskiego (określenie Mykoły Riabczuka) pojawiają się takie niebezpieczne elementy, jak mesjanizm narodowy, gloryfikacja własnej historii czy idealizacja narodu ukraińskiego (nierzadko połączona z deprecjacją innych narodów) ${ }^{22}$. W przypadku mitu trypilskiego — oraz spokrewnionych z nim ideowo i fabularnie ,prahistorycznych” opowieści — bez trudu odnajdujemy wymienione elementy. Po pierwsze, pojawia się tu istotny komponent autostereotypu Ukraińców — „wizja społeczności wyjątkowo uzdolnionych i produktywnych rolników, wręcz ojców światowej gospodarki agrarnej"23. Po drugie, gloryfikacja

${ }^{20}$ A. Wilson, op. cit., s. 26.

${ }^{21}$ К. Галушко, Трипільй - україниі?, „Тиждень” 2007, nr 24, http://tyzhden.ua/Publication/3042 [dostęp: 2.02.2016].

22 D. Gorun, op. cit., s. 183.

${ }^{23}$ A. Wilson, op. cit., s. 27. 
dziejotwórczych odkryć tej „cywilizacji” obraca się w podważenie osiągnięć innych narodów i prowadzi do przypisania całego kulturowego dorobku ludzkości własnej wspólnocie. To z kolei, w momencie gdy mit przechodzi w utopię, służy formułowaniu mesjanistycznych programów odbudowy potęgi narodu ukraińskiego.

Rozpowszechnienie i utrwalenie mitów historycznych w społeczeństwie ukraińskim miało też inne konkretne powody. Teorie Kanyhina i jemu podobnych, mimo iż większość profesjonalnych historyków odrzucała przytaczane przez nich argumenty, wcale nie były, jak konstatował w 2000 roku A. Wilson, pozbawionym wszelkiego znaczenia marginesem ukraińskiego życia intelektualnego ${ }^{24}$. Znaczny wpływ miała na to polityka historyczna władz ukraińskich. Głosu szerzycielom takich rewelacji udzielały bowiem nie tylko komercyjne środki masowego przekazu (które można by było podejrzewać o chęć sięgnięcia po łatwą sensację), lecz także media działające pod auspicjami państwa. Publikacje propagujące dzieła poświęcone dociekaniom na temat „,antyczności” kultury ukraińskiej pojawiały się między innymi na łamach gazety „Literaturna Ukrajina”, organu prasowego Związku Pisarzy Ukrainy. Gazeta Rady Najwyższej „Hołos Ukrajiny" oraz pierwszy program Państwowego Radia Ukrainy również regularnie użyczały miejsca orędownikom „odbudowy” tysiącletniej genetycznej pamięci Ukraińców. Książka J. Kanyhina Droga Arijów, która stała się bestselerem i miała pięć wydań, była emitowana w wersji audio przez Państwowe Radio Ukrainy. Swoją rolę odegrała również postawa polityków, w tym prezydentów Ukrainy. Jedna z prac Kanyhina poprzedzona została wstępem pióra byłego prezydenta Leonida Krawczuka ${ }^{25}$, a szczyt zainteresowania tematyką trypilską przypadł na okres rządów prezydenta Wiktora Juszczenki ${ }^{26}$. Nadal aktualnym przykładem podobnych działań jest audycja radiowa 3 глибини тисячоліть prowadzona przez Wałerija Bebyka, którą emituje Państwowa Radiokompania Ukrainy oraz również emitowany do dnia dzisiejszego przez prywatny kanał telewizyjny Tonis program telewizyjny tego samego autora Цивілізація INCOGNITA. Ponadto fala entuzjazmu dla odkrywania ,prawdziwych”, lecz niesłusznie zapomnianych stronic historii Ukrainy nie ominęła tak istotnego i wrażliwego miejsca dydak-

${ }^{24}$ Ibidem, s. 22.

${ }^{25}$ Chodzi o książkę Ю. Канигін, 3. Ткачук, Українська мрія, передмова Л. Кравчука, Київ, 1996. Podaję za: A. Wilson, op. cit., s. 22.

${ }^{26}$ Poczynania ukraińskich polityków nie stanowiły precedensu w postradzieckiej przestrzeni, np. założyciele litewskiego ruchu pogańskiego zostali w 1997 roku odznaczeni prestiżową nagrodą państwową Jonasa Basanavičiusa. Й. Тринкунас, Основатели литовского языческого движения награждены национальной премией, „Мифы и магия индоевропейцев” 1998, z. 7 , s. 176. Z kolei w Rosji w 2014 roku w ramach dyskusji o zawartości rosyjskich podręczników historii przewodniczący komitetu Dumy ds. Edukacji Wiaczesław Nikonow przekonywał: „Nasz kraj ma wielką przeszłość. Odgałęzienie aryjskiego plemienia zeszło z Karpat i pokojowo zasiedliło Wielką Równinę Rosyjską, Syberię, najzimniejszą część planety, doszło do Oceanu Spokojnego, założyło Fort Ross, żywiło się sokami najbogatszych kultur Bizancjum, Europy, Azji [...]”. Zob. http://www.duma.gov.ru/news/273/646438/ [dostęp: 2.02.2016]. 
tyki narodowej jak podręczniki szkolne i akademickie. Hipoteza o „trypilskim państwie Arrata, praojczyźnie Sumerów" trafiła do podręczników ${ }^{27}$, a studium Księgi Welesa zostało włączone do programu literatury ukraińskiej dla średnich szkól ogólnokształcących.

Niebezpieczeństwa związane $\mathrm{z}$ popularyzacją skrajnych przejawów romantycznego mitu narodowoukraińskiego nie mogły rzecz jasna nie wywołać reakcji środowiska naukowego. $\mathrm{Z}$ ostrą krytyką podobnych prób współczesnego mitotwórstwa wystąpił na łamach czasopisma „Krytyka” George Grabowicz. Badacz skoncentrował swoją uwagę na Księdze Welesa, która w jego przekonaniu jest nie tyle przykładem szlachetnej obróbki materiału folklorystycznego, jak w przypadku komponowania eposów ludowych innych narodów, ile nieudolną próbą mistyfikacji literackiej, pozostającą w kręgu poszukiwań okultystycznych oraz wskazującą na niebezpieczne tendencje wzrostu mitologizacji świadomości narodowej Ukraińców ${ }^{28}$. Przedstawiciele nauk historycznych, np. autorytet w dziedzinie archeologii Łeonid Zalizniak czy znany historyk Kyryło Hałuszko, również wielokrotnie zabierali głos $\mathrm{w}$ tej kwestii zarówno $\mathrm{w}$ formie publikacji naukowych, jak i w ramach dyskusji publicznych. W 2007 roku została utworzona seria Likbez-Абетка pod wiele mówiącym hasłem „Поєднаймо патріотизм зі здоровим глуздом!”. W 2008 roku w ramach tej serii ukazały się na przykład: monografia Походження українців: між наукою та ідеологією Ł. Zalizniaka, praca Народи, етноси, нації... autorstwa K. Hałuszki oraz tom Новітні міфи та фальшивки про походження українців prezentujący wyniki pracy okrągłego stołu pt. Міфологізаиія походження українців. Dzięki ostatniemu wydawnictwu ukraiński czytelnik mógł zapoznać się z punktem widzenia fachowców - historyków, archeologów oraz językoznawców, którzy udzielali odpowiedzi na pytania dotyczące między innymi rzetelności prezentowania zagadnień etnogenezy Ukraińców, a także starożytnej historii ziem ukraińskich w mediach, problemu nadmiernej polityzacji tych zagadnień, zagrożeń, które mogą być skutkiem mitologizacji dziejów Ukrainy czy znaczenia percepcji kultury trypilskiej dla kształtowania etnomitologii ${ }^{29}$.

Duży rezonans wzbudził opublikowany w 2012 roku otwarty list zespołu redakcyjnego czasopisma „Archeologia” do mediów ostro potępiający dyletanckie i prymitywne w swej istocie poczynania na polu historiografii. Autorzy listu odnoszą się bezpośrednio do działalności wspomnianego wcześniej profesora politologii Wałerija Bebyka, autora rewelacji, głoszących, że:

столицю Лівії м. Тріполі так назвали трипільські емігранти з України, єгипетські копти походять з України, бо тут є с. Коптилове, римський імператор Сулла — виходець

27 Я. Гордієнко, Errare huтапит еst. 50 нарисів з українського примарознавства, Київ 2014, s. 99.

28 Г. Грабович, Слідами наџіональних містифікацій, „Критика” 2001, nr 6, s. 16.

29 Л. Залізняк et al., Новітні міфи та фальшивки про походження украӥнців, Київ 2008, http://www.e-reading.club/bookreader.php/1013874/Novitni_mifi_ta_falshivki_pro_pohodzhennya_ukrainciv.html [dostęp: 2.02.2016]. 
із Посулля, засновники Риму Ромул і Рем - iз м. Ромни на Сумщині, з Сумщини ж походять легендарні шумери або сумери, а перший фараон Єгипту Менес — 3 райцентру Мена на Чернігівщині ${ }^{30}$.

Naukowcy nie szczędzą słów krytyki, oceniając poczynania zarówno W. Bebyka, jak i jemu podobnych poszukiwaczy ,prawdy” o historii Ukrainy, używając takich określeń jak: „профанація науки”, „прояв найгіршого сорту наївного історичного примітивізму та дилетантства”, „абсурдні та бездоказові марення”, „псевдонауковий жанр так зв. україністики, що вже отримав назву »трипологія«"31 itd. Pada również określenie „шовіністична маячня”, które nie jest bezpodstawne, ponieważ odwołania do teorii aryjskiej nieuchronnie wywołują w pamięci współczesnych poczynania władz hitlerowskich, które mit pierwotnej rasy białej uczyniły jednym z naczelnych założeń ideologii nazizmu $^{32}$. I chociaż zwolennicy ukraińskiej wersji teorii aryjskiej bronią jej, twierdząc, że jest to koncepcja czysto lingwistyczna, pozbawiona podtekstów rasowych, to jednak naukowcy słusznie zwracają uwagę, że rozpowszechnianie tego typu koncepcji jest prostą drogą do skompromitowania nie tylko ich autorów czy historiografii ukraińskiej, lecz także całego państwa ukraińskiego na arenie międzynarodowej.

Ostatnio argument dbania o reputację Ukrainy zyskał na sile w związku ze wzmożoną antyukraińską kampanią prowadzoną przez media rosyjskie, które skrzętnie wykorzystują wszelkie preteksty do zdyskredytowania Ukrainy. Niedawno w telewizji rosyjskiej pojawił się reportaż ośmieszający Ukraińców i przedstawiający w tym celu najbardziej kuriozalne i anegdotyczne koncepcje ukraińskiej etnogenezy ${ }^{33}$. W związku z tym ukraińscy historycy zaczęli wysuwać nie tylko zarzuty o koniunkturalizm, prymitywny dyletantyzm czy uprawianie źle pojętego patriotyzmu, lecz nawet podejrzenia o pracę. Chociaż naszym zdaniem do powyższych sugestii również należy podejść z odpowiednim dystansem. Niemniej jednak władze ukraińskie nie przestają dostarczać powodów do tego typu akcji medialnych. W kwietniu 2015 roku na czele Obywatelskiej Rady przy Ministerstwie Polityki Informacyjnej Ukrainy stanął Wałerij Bebyk, którego ultrapatriotyczne wysiłki na niwie historii zostały przecież należycie ocenione we wspomnianym liście ukraińskich archeologów ${ }^{34}$. To wydarzenie nie uszło uwa-

${ }^{30}$ Відкритий лист журналу „Археологія”..., s. 143.

${ }^{31}$ Ibidem, s. 145.

${ }^{32}$ Ibidem, s. 146.

33 Zob. Нова „сенсаиія” російських журналістів: „Укри викопали Чорне море, щуоб митиcя", http://visnyk.lutsk.ua/news/ukraine/nova-sensatsiya-rosiiskykh-zhurnalistiv-ukry-vykopalychorne-more-shchob-mytysya/ [dostęp: 2.02.2016].

${ }^{34}$ Ponadto w listopadzie 2015 roku Związek Pisarzy Ukrainy zgłosił program telewizyjny Цивілізація INCOGNITA, którego autorem jest W. Bebyk, do zdobycia najważniejszego wyróżnienia państwowego na Ukrainie - Państwowej Nagrody im. T. Szewczenki. Decyzją Komitetu Nagrody zgłoszenie przeszło do drugiego etapu konkursu. Ostatecznie nominowany projekt nie znalazł się w gronie laureatów nagrody w 2016 roku. Należy jednak zaznaczyć, że zarówno po- 
dze prasy ukraińskiej, a także, czego można było oczekiwać, znalazło natychmiastowy odzew w mediach rosyjskich o łatwym do przewidzenia charakterze.

Warto jednak pamiętać, że polityka historyczna Ukrainy to zarówno działania instytucjonalne, jak i inicjatywy społeczne, takie jak: projekty Historians. in.ua, Istoryczna Prawda czy Likbez. Istrorycznyj front. Ola Hnatiuk w następujący sposób charakteryzuje ich poczynania: „Robią to entuzjaści, nie dlatego, że są amatorami, bo to działania niezwykle profesjonalne, ale ponieważ te wszystkie poczynania są prowadzone pozainstytucjonalnie, bez wsparcia państwa, niejako poza nim" 35 . Należy jednak zauważyć, że przekształcenia polityczno-społeczne, które zainicjowała rewolucja godności, stopniowo zmieniają sytuację również w tej sferze. W kontekście podjętego tematu na szczególną uwagę zasługuje projekt Likbez. Istorycznyj front, stworzony we wrześniu 2014 roku przez grupę historyków ukraińskich ${ }^{36}$. Koncepcja zaproponowanego na tej platformie wykładu historycznego polega na tym, że badacze opatrują znakiem zapytania najbardziej rozpowszechnione mity i dają odpowiedź w formie popularnonaukowych tekstów opartych na faktach i dokumentach. Teksty są najpierw prezentowane na portalu internetowym, a potem stopniowo wchodzą w skład wydawnictw sygnowanych przez Likbez. Istorycznyj front. Początkowo zespół skupiał się na dekonstrukcji stereotypów wyprodukowanych przez radziecką i rosyjską propagandę. Stopniowo jednak pojawiały się tam również materiały sprostowujące najpopularniejsze mity ukraińskie, między innymi te dotyczące „prahistorycznych" dziejów Ukraińców. Badacze uczestniczący w projekcie wydali w 2014 roku pod pseudonimem Jakiw Hordijenko książkę pt. Errare humanum est. 50 нарисів з українського примарознавства ${ }^{37}$. Ta popularnonaukowa publikacja skupia się wyłącznie na „wewnątrzkrajowych” mitach, które autorzy traktują jako dziecięce choroby czy dorosłe kompleksy znane $\mathrm{z}$ historii dojrzewania wielu narodów. Można powiedzieć, że refleksja tych naukowców nad charakterem funkcjonowania mitów historycznych współbrzmi z opinią Andrew Wilsona,

czynania decydentów ZPU, jak i decyzje Komitetu Nagrody już od wielu lat wzbudzają liczne kontrowersje w ukraińskich kręgach opiniotwórczych.

${ }^{35}$ O. Hnatiuk, Dyskusja: Polityka tożsamości i pamięci na Ukrainie, [w:] Pamięć i pytania o tożsamość..., s. 60.

${ }^{36}$ Kyryło Hałuszko, jeden z założycieli projektu Likbez. Istorycznyj front, zaznacza, że przedsięwzięcia, które realizuje zespół, należy nazwać społecznymi, ponieważ nie są one wykonywane na zamówienie oficjalnych organizacji czy struktur. Niemniej jednak, jak podkreśla badacz, działalność projektu cieszy się pełnym poparciem Instytutu Historii Ukrainy NAN Ukrainy, Wydziału Historycznego Narodowego Uniwersytetu im. T. Szewczenki w Kijowie, Narodowego Muzeum Historii Ukrainy oraz Ukraińskiego Instytutu Pamięci Narodowej. Кирилл Галушко: „Главное оружие украинского историка - факты и просветительство”. Rozmawiał С. Махун, „Дзеркало тижня” 26.02.2016 [dostęp: 2.02.2016]. Ponadto przedstawicieli projektu zaczęto regularnie zapraszać do audycji oświatowej Суспільний університет emitowanej na antenie pierwszego programu ukraińskiej telewizji państwowej od października 2015 roku.

37 Ta publikacja nie była bezpośrednio sygnowana przez Likbez. Istorycznyj front, natomiast pod marką projektu ukaże się niebawem tom pt. Тіні незабутих предків роświęcony pochodzeniu Ukraińców oraz historii ziem ukraińskich od starożytności do rozkwitu Rusi Kijowskiej. 
który twierdzi, że „naród o częściowo zafałszowanej i zmitologizowanej świadomości historycznej nie przestaje przez to być narodem"38. Niemniej jednak główna intencja autorów jest wyraźnie określona przez aktualną sytuację oraz entuzjazm rewolucji godności, związany $\mathrm{z}$ wiarą $\mathrm{W}$ możliwość pozbycia się przez Ukrainę balastu przestarzałych modeli myślenia, w tym zrezygnowania ze strategii narodotwórczych prowadzących na niwie historii i kultury na manowce mitotwórstwa.

\section{Bibliografia}

Assman J., Kultura pamięci, [w:] Pamięć zbiorowa i kulturowa. Współczesna perspektywa niemiecka, red. M. Saryusz-Wolska, Kraków 2009, s. 59-100.

Gorun D., Mity współczesnej Ukrainy: krótki przegląd, „Sprawy Narodowościowe” 2002, z. 21, s. $179-190$.

Hnatiuk O., Dyskusja: Polityka tożsamości i pamięci na Ukrainie, [w:] Pamięć i pytania o tożsamość. Polska. Ukraina, red. T. Horbowski, P. Kosiewski, Warszawa 2013, s. 59-61.

Kozak S., Ukraiński dialog z tradycja kultury narodowej, [w:] Współcześni Słowianie wobec własnych tradycji i mitów, red. M. Bobrownicka, L. Suchanek, F. Ziejka, Kraków 1997, s. $159-166$.

Rotfeld A.D., Dyskusja: Polityka tożsamości i pamięci na Ukrainie, [w:] Pamięć i pytania o tożsamość. Polska. Ukraina, red. T. Horbowski, P. Kosiewski, Warszawa 2013, s. 27-31.

Saryusz-Wolska M., Wprowadzenie, [w:] Pamięć zbiorowa i kulturowa. Współczesna perspektywa niemiecka, red. M. Saryusz-Wolska, Kraków 2009, s. 7-38.

Traverso E., Historia jako pole bitwy. Interpretacja przemocy w XX wieku, tłum. Ś.F. Nowicki, Warszawa 2014.

Wilson A., Ukraińcy, tłum. M. Urbański, Warszawa 2004.

Wyrozumski J., Mity o pochodzeniu, [w:] Współcześni Słowianie wobec własnych tradycji i mitów, red. M. Bobrownicka, L. Suchanek, F. Ziejka, Kraków 1997, s. 15-22.

Андрющенко Е., Украӥнські праворадикальні організації у контексті суспільно-політичних процесів (кінець 1980-х-2015 pp.), http://shron.chtyvo.org.ua/Andriuschenko_Eduard/ Ukrainski_pravoradykalni_orhanizatsii_u_konteksti_suspilno-politychnykh_protsesiv_ kinets_1980-kh_20.pdf [dostęp: 2.02.2016].

Богдановський І.В., Відновлення національно-духовних традииій в сучасному язичництві, „Вісник Київського національного університету імені Тараса Шевченка. Філософія. Політологія" 2012, z. 107, s. 8-11.

Відкритий лист редколегї̈ журналу „Археологія” до мас-медіа Украӥни, „Археологія” 2012, nr 3, s. 143-147.

Галушко К., Народи, етноси, нації..., Київ 2008.

Галушко К., Трипільияі - украӥнціi?, „Тиждень” 2007, nr 24, http://tyzhden.ua/Publication/3042 [dostęp: 2.02.2016].

Гордієнко Я., Errare huтnuт Est. 50 нарисів з українського примарознавства, Київ 2014.

Грабович Г., Слідами національних містифікацій, „Критика” 2001, nr 6, s. 14-23.

Залізняк Л., Походження українців: між наукою та ідеологією, Київ 2008.

Залізняк Л., Україногенез в тумані міфологіï, http://nestor-ua.org/projects/etnogenez-ua5.html [dostęp: 2.02.2016].

38 A. Wilson, op. cit., s. 39.

Slavica Wratislaviensia 163, 2016

(C) for this edition by CNS 
Залізняк Л. et al., Новітні міфи та фальшивки про походження українців, Київ 2008.

Кирилл Галушко: „Главное оружие украинского историка - факты и просветительство”.

Rozmawiał C. Махун, „Дзеркало тижня” 26.02.2016 [dostęp: 2.02.2016].

Плохій С., Походження слов'янських націй. Домодерні ідентичності в Украӥні, Росї та Білорусі, Київ 2015.

Рогатін В.М., Модифікації язичництва в сучасному неоязичництві, „Історичний архів.

Наукові студії: збірник наукових праць” 2012, z. 9, s. 169-174.

Толочко А., Очерки начальной Руси, Киев 2015.

Тринкунас Й., Основатели литовского языческого движения награждены национальной премией, „Мифы и магия индоевропейцев” 1998, z. 7.

\section{Is a nation like fine wine - the older the better? (Re)formation of nation genealogy vs. nation-building strategies}

\section{Summary}

The proposed article explores the symbolism of the terms "old" and "old age" from the perspective of cultural considerations on national communities. Focusing on connections between historical memory and the process of shaping national identity, the author analyzed selected variants of the origin myth (including a number of quasihistorical theories on the ethnogenesis of Ukrainians) operating in Ukrainian public sphere. The author not only characterized them showing their effect on Ukrainian public opinion, but also showed selected causes of their creation, such as the imperative to rebuild genealogical memory of the nation, cultivating romantic national mythology, and the need of a positive national auto-stereotype. Moreover, the author described several examples of the reaction of the Ukrainian scientific community on mythmaking cases in the field of national history.

Keywords: history, identity, Aryan theory, ethnogeny, myth

\section{Чи народ, як і вино - чим старіший, тим краще? (Від)творення генеалогії народу з перспективи народотворчих стратегій}

Резюме

Стаття розглядає символіку визначень „старий”, „старість” з перспективи культурологічних роздумів над національними спільнотами. В центр уваги автора потрапив зв'язок питань історичної пам'яті з процесом формування національної ідентичності. Проаналізовано вибрані варіанти міфу початку (головним чином низку квазіісторичних теорій етногенезу українського народу), які функціонують в українському публічному просторі. Здійснено їх загальну характеристику, показано їхній вплив на українське суспільство, а також вказано на такі причини їхньої появи як: імператив відбудови генеалогічної пам'яті народу, плекан- 
ня романтичної національної міфології, потреба формування позитивного національного автостереотипу тощо. Описано також приклади реакції наукового середовища України на випадки такої міфотворчості на ниві національної історії.

Ключові слова: історія, ідентичність, арійська теорія, етногенез, міф 